\title{
Modelling Dispersion Influences on Chromium Transport in Heterogeneous Silty and Fine sand Formation, Port Harcourt Industrial Lay-Out, Rivers State of Nigeria
}

\author{
Eluozo S. N. ${ }^{1}$, Amagbo L. G. ${ }^{2}$ \\ ${ }^{1}$ Civil and Environmental Engineering, Research and Development, Subaka Nigeria Limited, Port Harcourt, Nigeria \\ ${ }^{2}$ Department of Chem-Petrochemical Engineering, Faculty of Engineering, Rivers State University of Science and Technology, Port \\ Harcourt, Nigeria
}

\section{Email address:}

solondu2015@yahoo.com (Eluozo S. N.), soloeluozo2013@hotmail.com (Eluozo S. N.), amagbolloyd@gmail.com (Amagbo L. G.), delloyd4eva@yahoo.com (Amagbo L. G.)

\section{To cite this article:}

Eluozo S. N., Amagbo L. G. Modelling Dispersion Influences on Chromium Transport in Heterogeneous Silty and Fine sand Formation, Port Harcourt Industrial Lay-Out, Rivers State of Nigeria. American Journal of Bioscience and Bioengineering. Vol. 5, No. 2, 2017, pp. 56-64. doi: $10.11648 /$ j.bio. 20170502.11

Received: September 30, 2016; Accepted: December 29, 2016; Published: March 4, 2017

\begin{abstract}
This paper examined chromium transport through dispersion and storage coefficient influences. The study has monitored the deposition of chromium in silty and fine sand formation. The developed model expressed the behaviour of chromium in the study location, storage coefficient and dispersions of chromium were examined through the behaviour of chromium transport in silty and fine sand formation, the behaviour were expressed through graphical representation, the fluctuation on concentration reflect the influences from porosity variation thus dispersion and storage coefficient. This generated slight accumulation of chromium deposition in silty and fine sand formation, this condition was examined through the rate of chromium deposition; some fluctuations were experienced from the experimental values for model validation. The heterogeneous settings in the formation were also observed, the developed model was compared with other experimental values, and both parameters expressed favourable fits validating the model.
\end{abstract}

Keywords: Dispersion, Storage Coefficients, Chromium and Heterogeneous Formation

\section{Introduction}

For several years experts in different dimension has been developed various sources of heavy metal, more soil were examined to deposited over a billion individual cells and estimation of 104-105 distinct genomes per gram of soil $[15,18,19$ and 23$]$, it is observed that bacteria in soil are the reservoirs for much of Earth's genetic biodiversity. This vast phylogenetic and efficient diversity can be attributed to the dynamic physical and chemical heterogeneity of soil, the results has express spatial and temporal separation of microorganisms including chemical constituents [8-10]. More so it is observed from high diversity of carbon (C) - rich compounds in soils, it has been observed that the ability of each taxon to compete for only a subset of resources could also contribute to the high diversity of bacteria including chemicals of natural origin in soils through resource partitioning [9-11, and 13]. Indeed, [10, 14 and 17] this were thoroughly express through distinct substrate preferences by broad microbial groups in grassland soils relating it to natural chemical deposition and $\mathrm{C}$ resource partitioning it, such condition demonstrate some key that contribute patterning of bacterial co-existence in model communities on plant surfaces [7, 12-13, and 14]. The development of highthroughput tools to evaluate the composition of soil bacterial communities is rapidly contributing to an enhanced perceptive of bacterial diversity and biogeographically distribution [4-6, and 11]. However, our ability to evaluate the purpose of different bacterial taxa has not reserved pace [15 - 16]. There are some limits in defining the consequences shifting community in response 
to environmental change [1-3, and 16]. Numerous concepts applied to monitor the trace of the bacteria for this reason, the application of tracer molecules such as stable-isotopes and the thymidineanalog, 3bromodeoxyuridine (BrdU), have been widely accept. Effort to connect phylogeny to function will be easier through this process. Stable-isotopes, particularly the heavy carbon isotope $13 \mathrm{C}$, have been regularly applied to recognize microbial community members capable of catabolizing particular substrates [17-21, and 23]. This method requires separation of nucleic acids based on buoyant density, so high concentrations of isotopically labeled substrate are needed. This approach was first applied to the study of bacterial populations over a decade ago [21-22] and it has since been used to categorize soil bacterial taxa that respond to various environmental stimuli [2-3 and 6]. Recently, BrdU incorporation has been shown to detect a broad diversity of bacterial phyla in marine system [4-8 and 19] [and fungal taxa in temperate $[13,22]$ (and boreal forest soils [5-8 and 20].

\section{Theoretical Background}

The behaviour of chromium in the soil has been observed by experts in different dimension, the rate of migration in soil and water environment are monitored through various way under the influences of flow in the soil through various formation characteristics, the study of storage coefficient including dispersion of chromium in Phreatic bed influencing it transport process has not been thoroughly expressed. This implies that the migration of the chromium through these sources has not been evaluated from this study, the rate of dispersions of the chromium are through these flows, these are base on the fluctuation rate on its permeation of the formation between the lithology in the study area.

\section{Governing Equation}

$$
\begin{aligned}
& D \frac{d^{2} c}{d x^{2}}-S T \frac{d c}{d x}+V_{t} \frac{d c}{d x}=0 \\
& D \frac{d^{2} c}{d x^{2}}-\left(S T-V_{t}\right) \frac{d c}{d x}=0
\end{aligned}
$$

Let $C=\sum_{n=0}^{\infty} a_{n} x^{n}$

$$
\begin{gathered}
C^{1}=\sum_{n=1}^{\infty} n a_{n} x^{n-1} \\
C^{11}=\sum_{n=2}^{\infty} n(n-1) a_{n} x^{n-2} \\
D \sum_{n=2}^{\infty} n(n-1) a_{n} x^{n-2}-\left(S T-V_{t}\right) \sum_{n=1}^{\infty} n a_{n} x^{n-1}=0
\end{gathered}
$$

Replace $n$ in the $1^{\text {st }}$ term by $n+2$ and in the $2^{\text {nd }}$ term by $n+1$, so that we have;

$$
\begin{gathered}
D \sum_{n=2}^{\infty}(n+2)(n+1) a_{n+2} x^{n}-\left(S T-V_{t}\right) \sum_{n=0}^{\infty}(n+1) a_{n+1} x^{n}=0 \\
\text { i.e. } D(n+2)(n+1) a_{n+2}=\left(S T-V_{t}\right)(n+1) a_{n+1} \\
a_{n+2}=\frac{\left(S T-V_{t}\right)(n+1) a_{n+1}}{D(n+2)(n+1)} \\
a_{n+2}=\frac{\left(S T-V_{t}\right) a_{n+1}}{D(n+2)} \\
\text { for } n=0, a_{2}=\frac{\left(S T-V_{t}\right) a_{1}}{2 D}
\end{gathered}
$$




$$
\begin{gathered}
\text { for } n=1, a_{3}=\frac{\left(S T-V_{t}\right) a_{2}}{3 D}=\frac{\left(S T-V_{t}\right)^{2} a_{1}}{2 D \bullet 3 D} \\
\text { for } n=2 ; a_{4}=\frac{\left(S T-V_{t}\right) a_{3}}{4 D}=\frac{\left(S T-V_{t}\right)}{4 D} \bullet \frac{\left(S T-V_{t}\right) a_{1}}{3 D \bullet 2 D}=\frac{\left(S T-V_{t}\right)^{3} a_{1}}{4 D \bullet 3 D \bullet 2 D} \\
\text { for } n=3 ; a_{5}=\frac{\left(S T-V_{t}\right) a_{4}}{5 D}=\frac{\left(S T-V_{t}\right)}{5 D \bullet 4 D \bullet 3 D \bullet 2 D} \\
\quad \text { for } n ; a_{n}-\frac{\left(S T-V_{t}\right)^{n-1} a_{1}}{D^{n-1} n !} \\
=a_{0}+a_{1} x+\frac{\left(S T-V_{t}\right) a_{1} x^{2}}{2 ! D}+\frac{\left(S T-V_{t}\right) a_{2} x^{3}}{3 ! D^{2}}+\frac{\left(S T-V_{t}\right) a_{1} x^{4}}{4 ! D^{3}}+\frac{\left(S T-V_{t}\right) a_{1} x^{5}}{5 ! D^{4}}+\ldots \\
C(x)=a_{0}+a_{1}\left[x+\frac{\left(S T-V_{t}\right) x^{2}}{2 ! D}+\frac{\left(S T-V_{t}\right) x^{3}}{3 ! D^{2}}+\frac{\left(S T-V_{t}\right) x^{4}}{4 ! D^{3}}+\frac{\left(S T-V_{t}\right) x^{5}}{5 ! D^{4}}\right] \\
C(x)=a_{0}+a_{1} \ell^{\frac{(S T-V)}{D}} x
\end{gathered}
$$

Subject equation (16) for the following boundary conditions

$$
\begin{gathered}
C(o)=0 \text { and } C(o)=H \\
C(x)=a_{0}+a_{1} \ell^{\frac{(S T-V)}{D} x} \\
C(o)=a_{0}+a_{1}=0 \\
\text { i.e. } a_{0}+a_{1}=0 \\
C^{1}(x)=\frac{\left(S T-V_{t}\right)}{2 ! D} a_{1} \ell^{\frac{\left(S T-V_{t}\right)}{D} x} \\
C^{1}(o)=\frac{\left(S T-V_{t}\right)}{2 ! D} a_{1}=H \\
a_{1}=\frac{H D}{S T-V_{t}}
\end{gathered}
$$

Substitute (18) into equation (17)

$$
\begin{gathered}
a_{1}=a_{0} \\
\Rightarrow a_{0}=\frac{-H D}{S T-V_{t}}
\end{gathered}
$$

Hence the particular solution of equation (16) is of the form:

$$
C(x)=-\frac{H D}{S T-V_{t}}+\frac{H D}{S T-V_{t}} \ell^{\frac{\left(S T-V_{t}\right)}{D} x}
$$




$$
\Rightarrow C(x)=\frac{H D}{S T-V_{t}}\left[e^{\frac{\left(S T-V_{t}\right)}{D} x}-1\right]
$$

\section{Materials and Method}

Standard laboratory experiment where performed to monitor the concentration of chromium depositions indifferent formation, applying AAS to monitor various rates of concentration in different strata, the soil strata were collected in sequences base on the structural deposition at different locations, this samples collected at different location generated variation at different depth producing different migration of chromium concentration through pressure flow at different strata, the experimental result are applied to be compared with the theoretical values to determined the validation of the model.

\section{Result and Discussion}

Results and discussion are presented in tables including graphical representation of chromium concentration

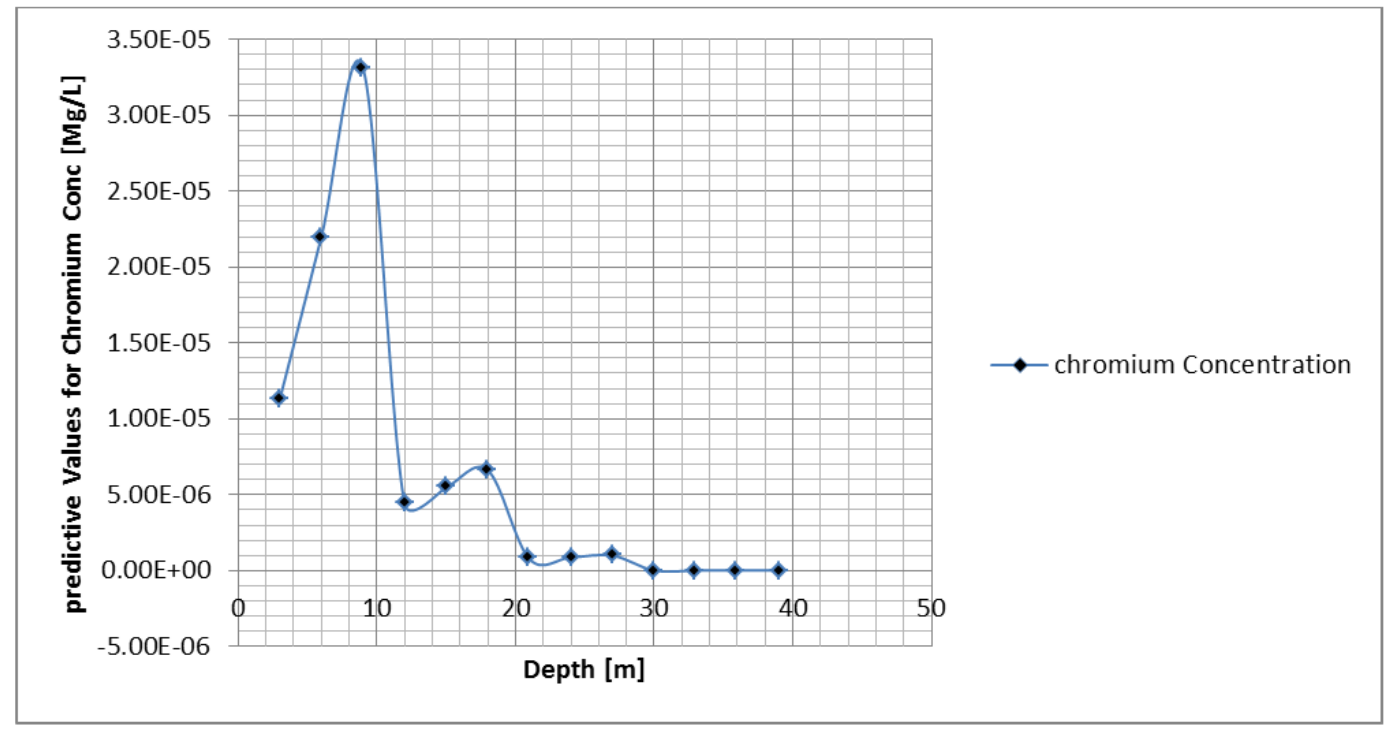

Figure 1. Concentration of chromium at Different Depth.

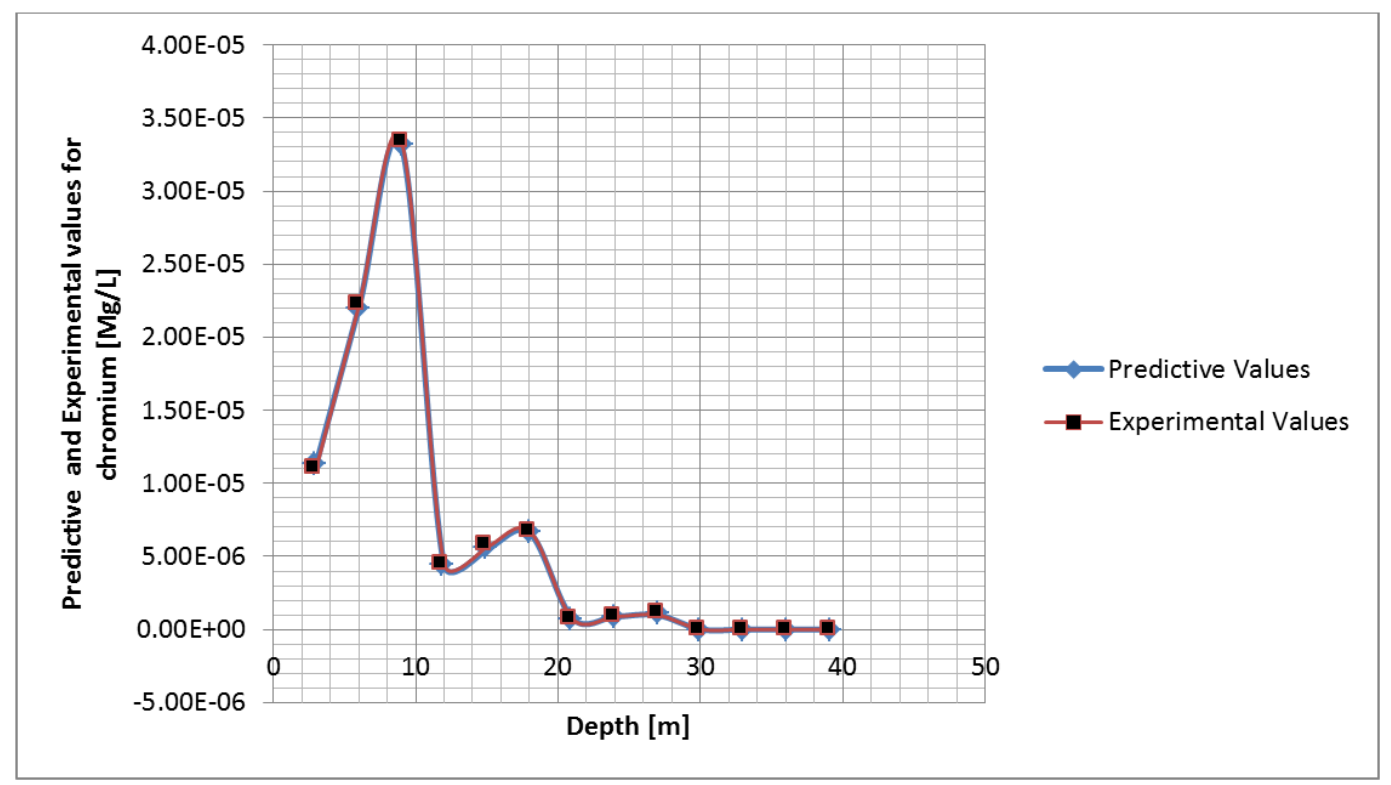

Figure 2. Predicted and Validate Concentration of chromium at Different Depth. 


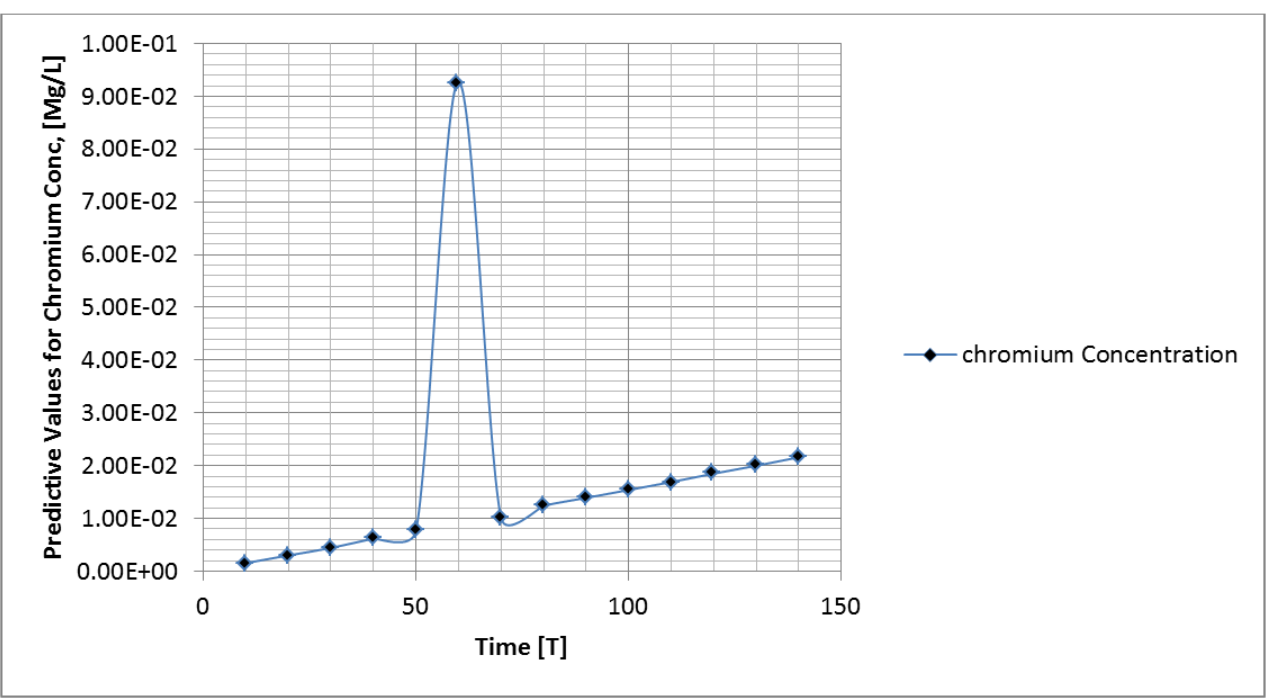

Figure 3. Concentration of chromium at Different Depth.

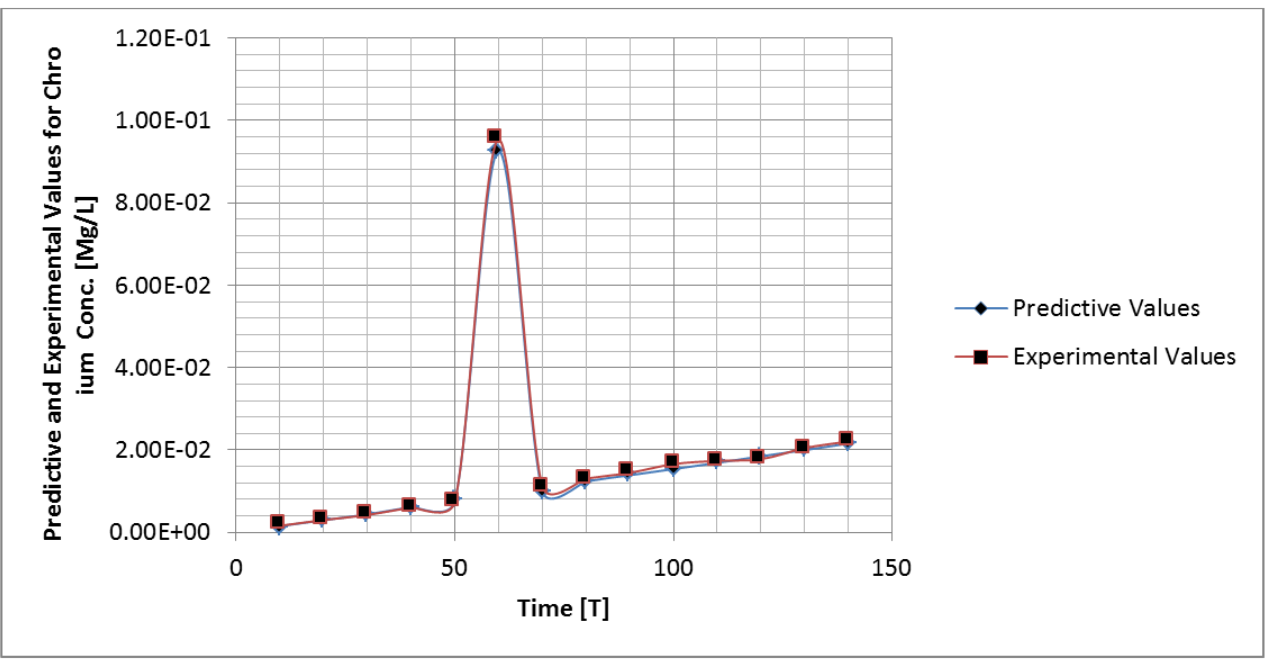

Figure 4. Predicted and Validate Concentration of chromium at Different Depth.

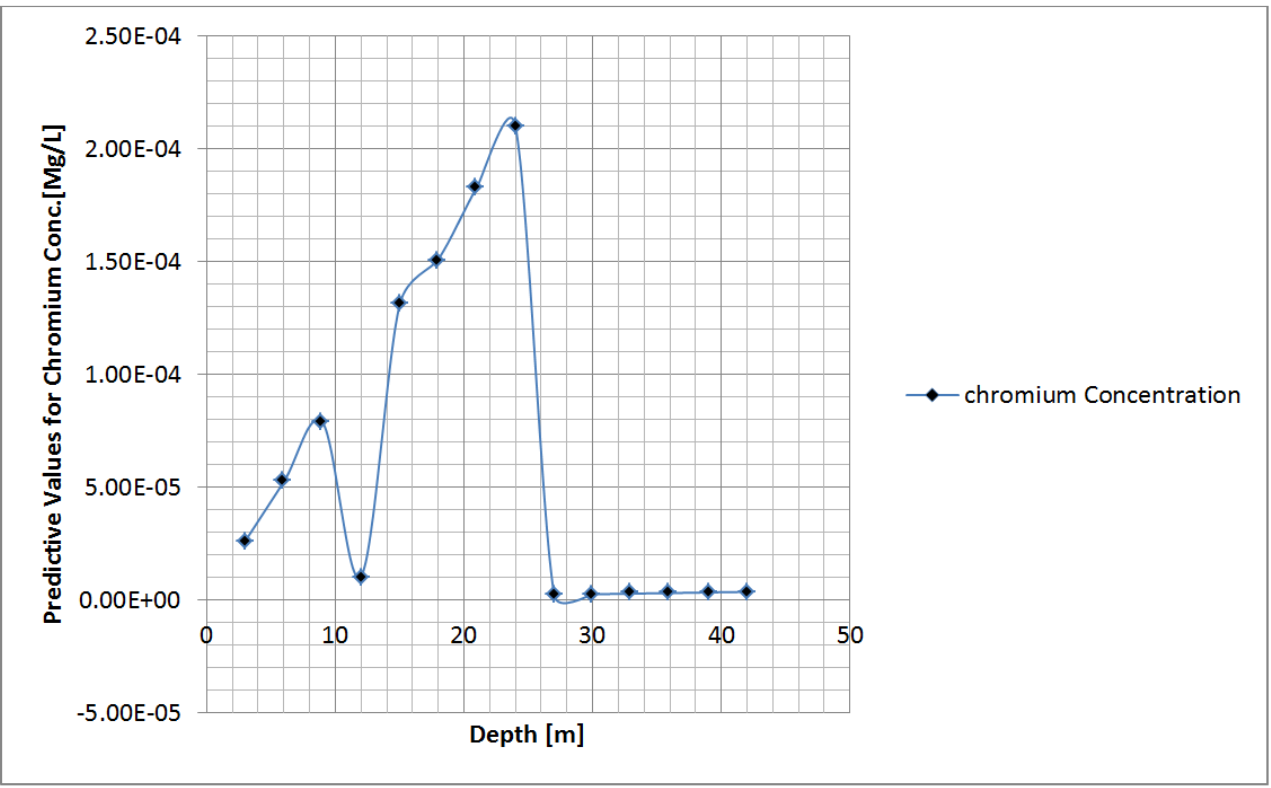

Figure 5. Concentration of chromium at Different Depth 

Silty and Fine sand Formation, Port Harcourt Industrial Lay-Out, Rivers State of Nigeria

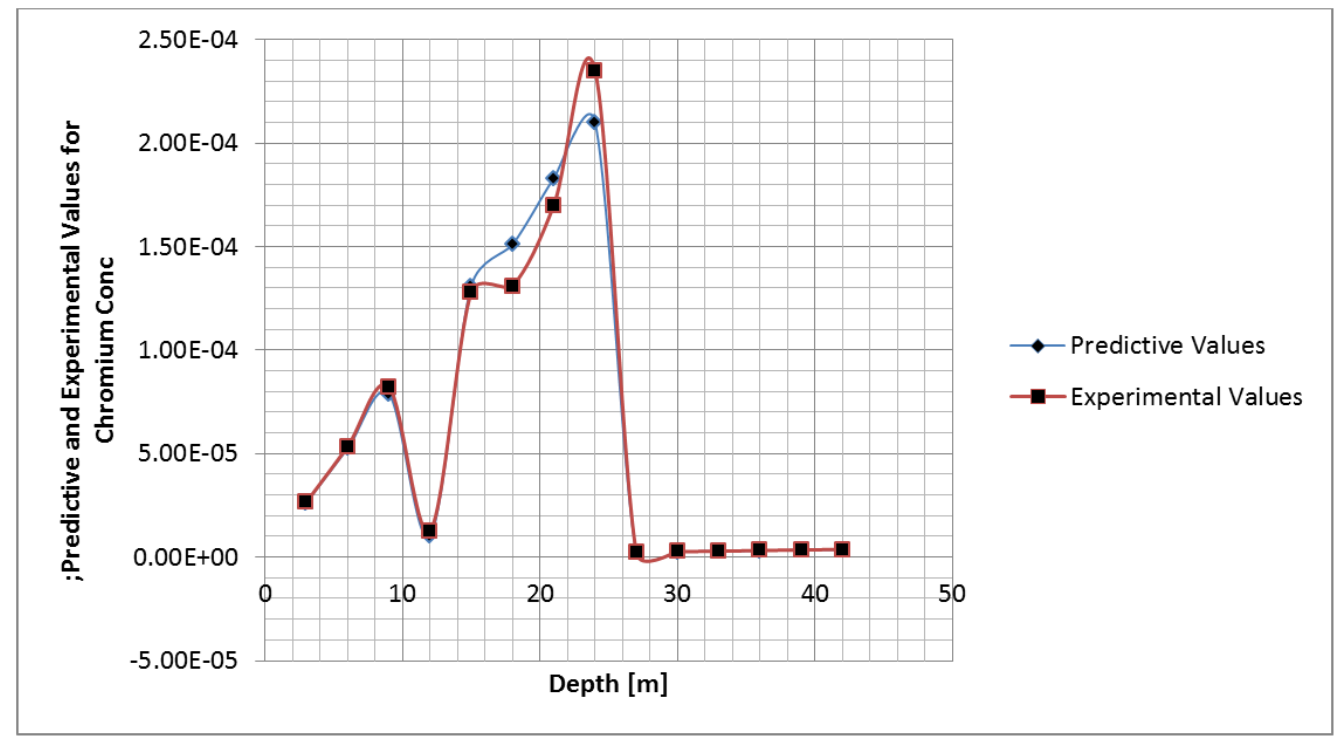

Figure 6. Predicted and Validate Concentration of chromium at Different Depth.

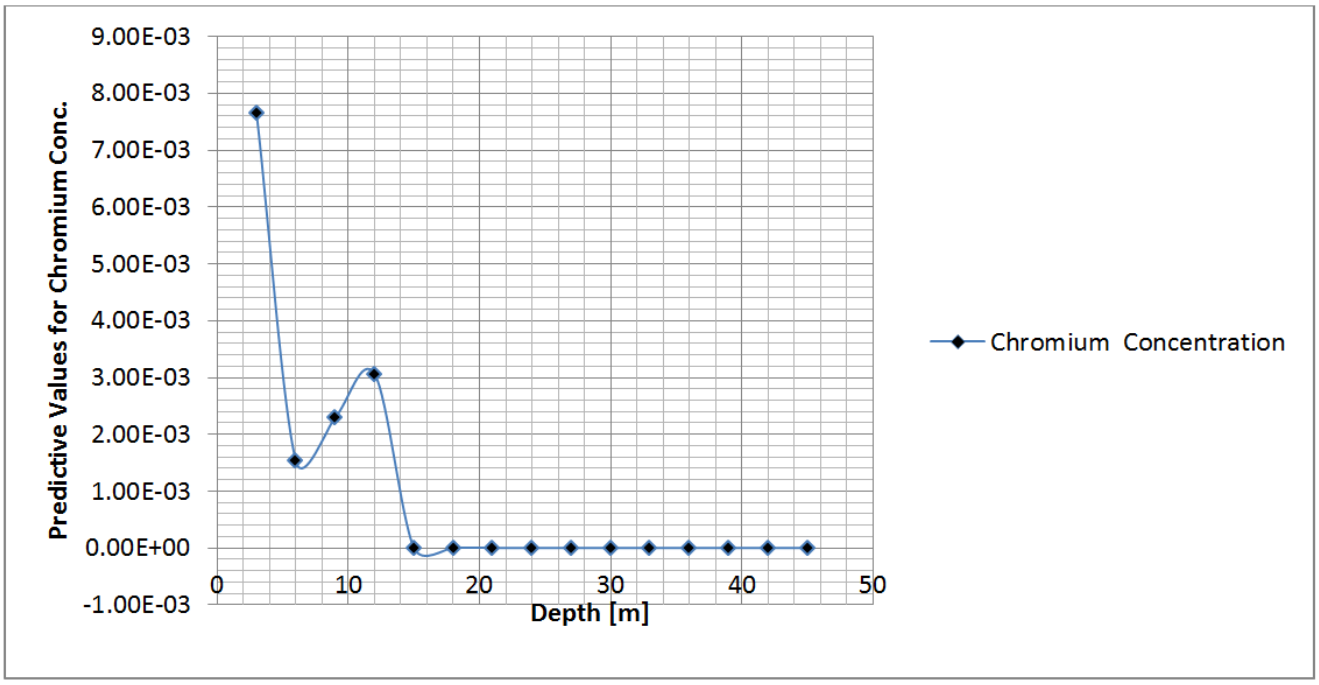

Figure 7. Concentration of chromium at Different Depth.

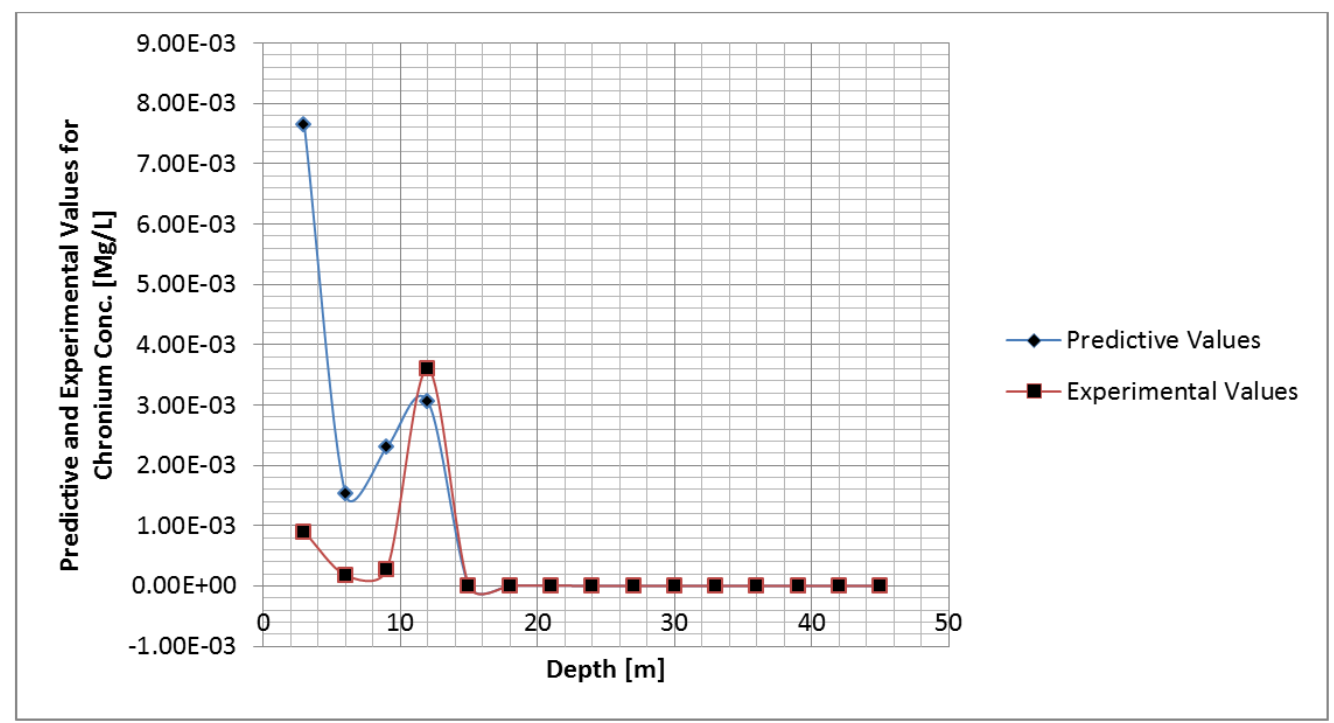

Figure 8. Predicted and Validate Concentration of chromium at Different Depth. 
Table 1. Concentration of chromium at Different Depth.

\begin{tabular}{ll}
\hline Depth $[\mathbf{M}]$ & chromium Concentration \\
\hline 3 & $1.13 \mathrm{E}-05$ \\
6 & $2.20 \mathrm{E}-05$ \\
9 & $3.31 \mathrm{E}-05$ \\
12 & $4.41 \mathrm{E}-06$ \\
15 & $5.51 \mathrm{E}-06$ \\
18 & $6.62 \mathrm{E}-06$ \\
21 & $7.72 \mathrm{E}-07$ \\
24 & $8.82 \mathrm{E}-07$ \\
27 & $9.93 \mathrm{E}-07$ \\
30 & $1.10 \mathrm{E}-08$ \\
33 & $1.21 \mathrm{E}-08$ \\
36 & $1.32 \mathrm{E}-08$ \\
39 & $1.43 \mathrm{E}-08$ \\
\hline
\end{tabular}

Table 2. Predicted and Validate Concentration of chromium at Different Depth.

\begin{tabular}{lll}
\hline Depth [M] & Predictive Values & Experimental Values \\
\hline 3 & $1.13 \mathrm{E}-05$ & $1.10 \mathrm{E}-05$ \\
6 & $2.20 \mathrm{E}-05$ & $2.21 \mathrm{E}-05$ \\
9 & $3.31 \mathrm{E}-05$ & $3.34 \mathrm{E}-05$ \\
12 & $4.41 \mathrm{E}-06$ & $4.48 \mathrm{E}-06$ \\
15 & $5.51 \mathrm{E}-06$ & $5.66 \mathrm{E}-06$ \\
18 & $6.62 \mathrm{E}-06$ & $6.74 \mathrm{E}-06$ \\
21 & $7.72 \mathrm{E}-07$ & $7.44 \mathrm{E}-07$ \\
24 & $8.82 \mathrm{E}-07$ & $8.85 \mathrm{E}-07$ \\
27 & $9.93 \mathrm{E}-07$ & $9.88 \mathrm{E}-07$ \\
30 & $1.10 \mathrm{E}-08$ & $1.21 \mathrm{E}-08$ \\
33 & $1.21 \mathrm{E}-08$ & $1.31 \mathrm{E}-08$ \\
36 & $1.32 \mathrm{E}-08$ & $1.42 \mathrm{E}-08$ \\
39 & $1.43 \mathrm{E}-08$ & $1.52 \mathrm{E}-08$ \\
\hline
\end{tabular}

Table 3. Concentration of chromium at Different Depth.

\begin{tabular}{ll}
\hline Time Per Day & chromium Concentration \\
\hline 10 & $1.54 \mathrm{E}-03$ \\
20 & $3.00 \mathrm{E}-03$ \\
30 & $4.41 \mathrm{E}-03$ \\
40 & $6.18 \mathrm{E}-03$ \\
50 & $7.72 \mathrm{E}-03$ \\
60 & $9.27 \mathrm{E}-02$ \\
70 & $1.01 \mathrm{E}-02$ \\
80 & $1.24 \mathrm{E}-02$ \\
90 & $1.39 \mathrm{E}-02$ \\
100 & $1.54 \mathrm{E}-02$ \\
110 & $1.69 \mathrm{E}-02$ \\
120 & $1.85 \mathrm{E}-02$ \\
130 & $2.00 \mathrm{E}-02$ \\
140 & $2.16 \mathrm{E}-02$ \\
\hline
\end{tabular}

Table 4. Predicted and Validate Concentration of chromium at Different Depth.

\begin{tabular}{lll}
\hline Time Per Day & Predictive Values & Experimental Values \\
\hline 10 & $1.54 \mathrm{E}-03$ & $1.64 \mathrm{E}-03$ \\
20 & $3.00 \mathrm{E}-03$ & $3.04 \mathrm{E}-03$ \\
30 & $4.41 \mathrm{E}-03$ & $4.24 \mathrm{E}-03$ \\
40 & $6.18 \mathrm{E}-03$ & $6.09 \mathrm{E}-03$ \\
50 & $7.72 \mathrm{E}-03$ & $7.54 \mathrm{E}-03$ \\
60 & $9.27 \mathrm{E}-02$ & $9.54 \mathrm{E}-02$ \\
\hline
\end{tabular}

\begin{tabular}{lll}
\hline Time Per Day & Predictive Values & Experimental Values \\
\hline 70 & $1.01 \mathrm{E}-02$ & $1.12 \mathrm{E}-02$ \\
80 & $1.24 \mathrm{E}-02$ & $1.31 \mathrm{E}-02$ \\
90 & $1.39 \mathrm{E}-02$ & $1.45 \mathrm{E}-02$ \\
100 & $1.54 \mathrm{E}-02$ & $1.66 \mathrm{E}-02$ \\
110 & $1.69 \mathrm{E}-02$ & $1.74 \mathrm{E}-02$ \\
120 & $1.85 \mathrm{E}-02$ & $1.78 \mathrm{E}-02$ \\
130 & $2.00 \mathrm{E}-02$ & $2.05 \mathrm{E}-02$ \\
140 & $2.16 \mathrm{E}-02$ & $2.21 \mathrm{E}-02$ \\
\hline
\end{tabular}

Table 5. Concentration of chromium at Different Depth.

\begin{tabular}{ll}
\hline Depth $[\mathbf{M}]$ & chromium Concentration \\
\hline 3 & $2.62 \mathrm{E}-05$ \\
6 & $5.25 \mathrm{E}-05$ \\
9 & $7.88 \mathrm{E}-05$ \\
12 & $1.05 \mathrm{E}-05$ \\
15 & $1.31 \mathrm{E}-04$ \\
18 & $1.51 \mathrm{E}-04$ \\
21 & $1.83 \mathrm{E}-04$ \\
24 & $2.10 \mathrm{E}-04$ \\
27 & $2.36 \mathrm{E}-06$ \\
30 & $2.62 \mathrm{E}-06$ \\
33 & $2.89 \mathrm{E}-06$ \\
36 & $3.15 \mathrm{E}-06$ \\
39 & $3.41 \mathrm{E}-06$ \\
42 & $3.67 \mathrm{E}-06$ \\
\hline
\end{tabular}

Table 6. Predicted and Validate Concentration of chromium at Different Depth.

\begin{tabular}{lll}
\hline Depth $[\mathbf{M}]$ & Predictive Values & Experimental Values \\
\hline 3 & $2.62 \mathrm{E}-05$ & $2.65 \mathrm{E}-05$ \\
6 & $5.25 \mathrm{E}-05$ & $5.34 \mathrm{E}-05$ \\
9 & $7.88 \mathrm{E}-05$ & $8.24 \mathrm{E}-05$ \\
12 & $1.05 \mathrm{E}-05$ & $1.27 \mathrm{E}-05$ \\
15 & $1.31 \mathrm{E}-04$ & $1.28 \mathrm{E}-04$ \\
18 & $1.51 \mathrm{E}-04$ & $1.31 \mathrm{E}-04$ \\
21 & $1.83 \mathrm{E}-04$ & $1.70 \mathrm{E}-04$ \\
24 & $2.10 \mathrm{E}-04$ & $2.35 \mathrm{E}-04$ \\
27 & $2.36 \mathrm{E}-06$ & $2.28 \mathrm{E}-06$ \\
30 & $2.62 \mathrm{E}-06$ & $2.69 \mathrm{E}-06$ \\
33 & $2.89 \mathrm{E}-06$ & $2.86 \mathrm{E}-06$ \\
36 & $3.15 \mathrm{E}-06$ & $3.23 \mathrm{E}-06$ \\
39 & $3.41 \mathrm{E}-06$ & $3.50 \mathrm{E}-06$ \\
42 & $3.67 \mathrm{E}-06$ & $3.77 \mathrm{E}-06$ \\
\hline
\end{tabular}

Table 7. Concentration of Chromium at Different Depth.

\begin{tabular}{ll}
\hline Depth $[\mathbf{M}]$ & Chromium Concentration \\
\hline 3 & $7.65 \mathrm{E}-03$ \\
6 & $1.53 \mathrm{E}-03$ \\
9 & $2.30 \mathrm{E}-03$ \\
12 & $3.06 \mathrm{E}-03$ \\
15 & $3.83 \mathrm{E}-06$ \\
18 & $4.59 \mathrm{E}-06$ \\
21 & $5.31 \mathrm{E}-06$ \\
24 & $6.12 \mathrm{E}-07$ \\
27 & $6.89 \mathrm{E}-07$ \\
30 & $7.65 \mathrm{E}-07$ \\
33 & $8.45 \mathrm{E}-07$ \\
36 & $9.19 \mathrm{E}-08$ \\
39 & $9.96 \mathrm{E}-08$ \\
42 & $1.07 \mathrm{E}-08$ \\
45 & $1.15 \mathrm{E}-08$ \\
\hline
\end{tabular}


The study has show the behaviour of the system through graphical representation expressing the behaviour of the chromium. The figures show the level of transport at different concentration. Figure one to four expresses the migration system under fluctuation phase, it implies that the deposition maintained high concentration at three metres to the lowest at thirty nine metres, these also express the rate of depositions in various strata structured in the study area, the concentration of chromium were observed to develop rapid heterogeneity on migration process within figure one and two, these increase are with respect to change in depth base on the transport system, it is influenced by the variation of the heterogeneity in porosity, such porous medium were observed to influences the migration rate of chromium concentration in the study area, while figure three maintained similar condition like one and two, fluctuation were observed with the optimum values recorded at sixty days. These developments increase the rate of concentration, because if the fluid velocity decreases its accumulation it definitely will reflect on the fluctuation increase in concentration; these conditions were experiences from figure one to four. While figure five and six maintained similar experiences, migration process observed fluctuation where the optimum values were recorded at twenty seven metres, but with different rate of concentration in the formation, figure seven and eight express it in physical process from high to low concentration, this can be attributed to slight deposition of inhibitors including rate of heterogeneity from degree of porosity between those strata. But slight increment of concentration were observed in figure seven and eight, the variation from porosity level and deposition of inhibitors were found to reflect on the concentration rate of chromium in these figures, their transport rate maintained fluctuation phase with increase in concentration from change in depth and time, their behaviour observed in this condition are base on the rate of inhibition and variations observed from increase rate of porosity in the formation, the transport of chromium were observed through these developed simulated values, the comparative analysis between predictive and experimental values generated best fits validating the developed model for chromium transport.

\section{Conclusion}

The study defined the behaviour of chromium in silty and fine sand formation, the study discuses the heterogeneity in various rate of concentration under the influences of porosity variation on its rate of deposition. The variation and inhibition observed in the transport process are reflected on the deposition of chromium in the study area. the migration rate of chromium has expresses its behaviour deposited on silty and fine sand formation, the developed model were to monitor the rate of concentration through its fluctuation phase expressed in graphical representation, the vacillation of the chromium in the strata shows the rate of influences from the stated parameters, the developed model were compared with experimental values, both parameters developed favourable fits, the behaviour of chromium has been expressed thoroughly through the developed model simulation values, the transport system in silty and fine sand formation has express the refection of slight immobile velocity generating slight fluctuation and accumulation in the study area.

\section{References}

[1] Katherine C. Goldfarb $1 \uparrow$, Ulas Karaoz 1, China A. Hanson 2, Clark A. Santee 1, Mark A. Bradford 3, Kathleen K. Treseder 2, Matthew D. Wallenstein 4 and Eoin L. Brodie 12011 Differential growth responses of soil bacterial taxa to carbon substrates of varying chemical recalcitrance frontier microbiology.

[2] Artursson, V., Finlay, R. D., and Jansson, J. K. (2005). Combined bromodeoxyuridineimmunocapture and terminalrestriction fragment length polymorphism analysis highlights differences in the active soil bacterial metagenome due to glomusmosseae inoculation or plant species. Environ. Microbiol. 7, 1952-1966.

[3] Artursson, V., and Jansson, J. K. (2003). Use of bromodeoxyuridineimmunocapture to identify active bacteria associated with arbuscularmycorrhizal hyphae. Appl. Environ. Microbiol. 69, 6208-6215.

[4] Allison, S. D., Czimczik, C. I., and Treseder, K. K. (2008). Microbial activity and soil respiration under nitrogen addition in alaskan boreal forest. Glob. Change Biol. 14, 1156-1168.

[5] Buckley, D. H., Huangyutitham, V., Hsu, S. F., and Nelson, T. A. (2007). Stable isotope probing with $15 \mathrm{~N} 2$ reveals novel noncultivateddiazotrophs in soil. Appl. Environ. Microbiol. 73, 3196-3204.

[6] Borneman, J. (1999). Cultureindependent identification of microorganisms that respond to specified stimuli. Appl. Environ. Microbiol. 65, 3398-3400.

[7] Fierer, N., Bradford, M. A., and Jackson, R. B. (2007a). Toward and ecological classification of soil bacteria. Ecology $88,1354-1364$.

[8] Papke, R. T., and Ward, D. M. (2004). The importance of physical isolation to microbial diversification. FEMSMicrobiol. Ecol. 48, 293-303.

[9] Zhou, J., Xia, B., Treves, D. S., Wu, L. Y., Marsh, T. L., O'Neill, R. V., Palumbo, A. V., and Tiedje, J. M. (2002). Spatial and resource factors influencing high microbial diversity in soil. Appl. Environ. Microbiol. 68, 326-334.

[10] Waldrop, M. P., and Firestone, M. K. (2004). Microbial community utilization of recalcitrant and simple carbon compounds: impact of oak-woodland plant communities. Oecologia 138, 275-284.

[11] Wilson, M., and Lindow, S. E. (1994). Coexistence among epiphytic bacterial populations mediated through nutritional resource partitioning. Appl. Environ. Microbiol. 60, 44684477.

[12] Drenovsky, R. E., Steenwerth, K. L., Jackson, L. E., and Scow, K. M. (2009). Land use and climatic factors structure regional patterns in soil microbial communities. Glob. Ecol. Biogeogr. 19, 27-39. 
[13] Lauber, C. L., Hamady, M., Knight, R., and Fierer, N. (2009). Pyrosequencingbased assessment of soil $\mathrm{pH}$ as a predictor of soil bacterial community structure at the continental scale. Appl. Environ. Microbiol. 75, 5111-5120.

[14] Chu, H., Fierer, N., Lauber, C. L., Caporaso, J. G., Knight, R., and Grogan, P. (2010). Soil bacterial diversity in the arctic is not fundamentally different from that found in other biomes. Environ. Microbiol. 12, 2998-3006.

[15] Green, J. L., Bohannan, B. J. M., and Whitaker, R. J. (2008). Microbial biogeography: from taxonomy to traits. Science 320, 1039-1043.

[16] Stein, L. Y., and Nicol, G. W. (2011). Grand challenges in terrestrial microbiology. Front. Microbiol. 2:6. doi: 10.3389/fmicb.2011.00006 Stein, L. Y., and Nicol, G. W. (2011). Grand challenges in terrestrial microbiology. Front. Microbiol. 2:6. doi: 10.3389/fmicb.2011.00006.

[17] Radajewski, S., Ineson, P., Parekh, N. R., and Murrell, J. C. (2000). Stableisotope probing as a tool in microbial ecology. Nature 403, 646-649.

[18] Griffiths, R. I., Manefield, M., Ostle, N., McNamara, N., O'Donnell, A. G., Bailey, M. J., and Whiteley, A. S. (2004). $13 \mathrm{CO}_{2}$ pulse labelling of plants in tandem with stable isotope robing: methodological considerations for examining microbial function in the rhizosphere. J. Microbiol. Methods $58,119-129$.

[19] Feth El Zahar, H., Wafa, A., Richard, C., Thierry, H., Christine, M., Marie- France, M., Christophe, M., Lionel, R., Jèrùme, B., and Odile, B. (2007). Identification of cellulolytic bacteria in soil by stable isotope probing. Environ. Microbiol. $9,625-634$.

[20] Schwartz, E. (2007). Characterization of growing microorganisms in soil by stable isotope probing with $\mathrm{H} 218 \mathrm{O}$. Appl. Environ. Microbiol. 73, 2541-2546.

[21] Urbach, E., Vergin, K. L., and Giovannoni, S. J. (1999). Immunochemical detection and isolation of DNA from metabolically active bacteria. Appl. Environ. Microbiol. 65, 1207-1213.

[22] Yin, B., Crowley, D., Sparovek, G., De Melo, W. J., and Borneman, J. (2000). Bacterial functional redundancy along a soil reclamation gradient. Appl. Environ. Microbiol. 66, $4361-4365$.

[23] Eluozo. S. N and 2 Afiibor B. B (2013) mathematical model to monitor the behaviour of nitrogen on salmonella transport in homogenous fine sand in coastal area of port Harcourt, Niger delta of Nigeria World Journal of Science and Technology Research Vol. 1, No. 3, May 2013, PP: 53-66. 